\title{
TOLERANSI ANTAR UMAT BERAGAMA DI SMA SELAMAT PAGI INDONESIA BATU JATIM
}

\author{
Moh. Rifai*
}

\begin{abstract}
Abstrak
$\mathrm{M}$ asyarakat yang berada di Yayasan Selamat Pagi Indonesia bersifat majemuk, pembauran, yang mereka datang dari perwakilan seluruh propinsi yang ada di Indonesia dengan mempunyai
\end{abstract} keragaman adat istiadat, bahasa daerah, serta agama yang melekat pada diri mereka masing-masing. Sudah barang tentu terdapat beberapa perbedaanperbedaan yang muncul di sana.

Penelitian ini menggunakan pendekatan kualitatif fenomenologi dengan analisis model interaktif Strauss and Corbin, teknik pengumpulan data menggunakan observasi, wawancara dan dokumenter. Penelitian tentang Interaksi Sosial antar siswa multikultural, antar guru, antar guru dengan siswa, semuanya pada keluarga besar masyarakat yayasan Selamat Pagi Indonesia Batu menghasilkan temuan-temuan : 1) "Interaksi Sosial Siswa-siswi SMA Selamat Pagi Indonesia Batu di asrama tidak melihat perbedaan suku tapi melihat dari asas kebangsaan Indonesia (terjemahan dari Bhineka Tunggal Ika)". 2) "Interaksi Siswasiswi SMA Selamat Pagi Indonesia di asrama tidak harus satu agama tapi bisa berinteraksi satu kamar berbeda agama seperti dalam sila pertama Pancasila (bahwa di Indonesia di akui bermacam-macam agama)". 3) "Di SMA Selamat Pagi Indonesia terjadi sembahyang bersama seagama walaupun beda kamar mereka tinggal". 4) "Bahwa interaksi sosial siswa-siswi SMA Selamat Pagi Indonesia batu, terbangun tidak seperti kelaziman di SMA lainnya, tapi didasari dengan disiplin dan dengan keyakinan berketuhanan yang kuat".

Adapun kesimpulan dari Interaksi Sosial Siswa Multikultural di SMA Selamat Pagi Indonesia sebagai berikut : 1) Hal-hal yang mendasari Pola Interaksi Sosial. 2) Proses terbentuknya Toleransi. 3) Pemaknaan tradisi toleransi.

\section{Kata Kunci : Toleransi, keragaman, agama.}

* Dosen Prodi PPKn IKIP PGRI Madiun 


\section{PENDAHULUAN}

Indonesia merupakan salah satu negara multikultural terbesar di dunia. Kebenaran dari pernyataan ini dapat dilihat dari kondisi sosiokultural maupun geografis yang begitu beragam dan luas. Sekarang ini, jumlah pulau di wilayah Negara Kesatuan Republik Indonesia (NKRI) sekitar 13.000 pulau besar dan kecil. Populasi penduduknya berjumlah lebih dari \pm 256 juta jiwa, terdiri dari 300 suku yang menggunakan hampir 250 bahasa yang berbeda. Selain itu, mereka juga menganut agama dan kepercayaan yang beragam seperti Islam, Katolik, Kristen Protestan, Hindu, Budha, Konghucu serta \pm 136 macam aliran kepercayaan.

Keragaman ini, diakui atau tidak dapat menimbulkan berbagai persoalan seperti yang sekarang dihadapi bangsa ini. Korupsi, kolusi, nepotisme, premanisme, perseturuan politik, kemiskinan, kekerasan, separatisme, perusakan lingkungan dan hilangnya rasa kemanusiaan untuk menghormati hak-hak orang lain adalah bentuk nyata sebagai bagian dari multikulturalisme itu. Contoh yang lebih konkret dan sekaligus menjadi pengalaman pahit bagi bangsa ini adalah terjadinya pembunuhan besarbesaran terhadap masa pengikut Partai Komunis Indonesia (PKI) pada tahun 1965, kekerasan terhadap etnis Cina di Jakarta pada Mei 1998 dan perang Islam Kristen di Maluku Utara pada tahun 1999-2003. Rangkaian konflik itu tidak hanya merenggut korban jiwa yang sangat besar, akan tetapi juga telah menghancurkan ribuan harta benda penduduk, 456 gereja dan 30 masjid. Perang etnis antara warga Dayak dan Madura yang terjadi sejak tahun 1931 hingga tahun 2000 telah menyebabkan kurang lebih 3600 nyawa manusia melayang sia-sia.

\section{Berdasarkan permasalahan} seperti di atas, perlu kiranya dicari strategi khusus dalam memecahkan persoalan tersebut melalui berbagai bidang: sosial, politik, budaya, ekonomi dan pendidikan. Berkaitan dengan hal ini, maka pendidikan siswa multikultural menawarkan satu alternatif melalui penerapan strategi dan konsep pendidikan yang berbasis pada pemanfaatan keragaman yang ada di masyarakat, khususnya yang ada pada siswa 
seperti keragaman etnis, budaya, bahasa, agama, status sosial, gender, kemampuan, umur dan ras. Dan yang terpenting, strategi pendidikan ini tidak hanya bertujuan agar supaya siswa mudah memahami pelajaran yang dipelajarinya, akan tetapi juga untuk meningkatkan kesadaran siswa agar selalu berperilaku humanis, pluralis dan demokratis.

Oleh karena itu, hal terpenting yang perlu dicatat dalam pendidikan multikultural ini adalah. Seorang guru tidak hanya dituntut untuk menguasai dan mampu secara profesional mengajarkan mata pelajaran atau mata kuliah yang diajarkannya. Lebih dari itu, seorang pendidik (guru) juga harus mampu menanamkan nilai-nilai inti dari pendidikan multikultural seperti demokratis, humanisme dan pluralisme.

$$
\text { Dengan menggunakan }
$$

sekaligus mengimplementasikan strategi pendidikan yang mempunyai visi misi selalu menegakkan dan menghargai pluralisme. Demokrasi dan humanisme diharapkan untuk para siswa dapat menjadi generasi yang selalu menjunjung tinggi moralitas, kedisiplinan, kepedulian humanistik, dan kejujuran dalam berperilaku sehari-hari. Pada akhirnya, diharapkan bahwa permasalahan yang dihadapi bangsa ini, lambat laun dapat diminimalkan, karena generasi kita di masa yang akan datang adalah "generasi multikultural" yang menghargai perbedaan, selalu menegakkan nilai-nilai demokrasi, keadilan dan kemanusiaan.

Bhineka Tunggal Ika di Indonesia adalah suatu keniscayaan. Sementara itu, pendidikan multikultural adalah sangat penting artinya bagi eksistensinya Negara Kesatuan Republik Indonesia (NKRI). Oleh karena itu, perlu suatu institusi untuk melestarikan dan menstransmisi pendidikan multicultural dalam kontek menejemen pendidikan, maka sekolah adalah di pandang lembaga yang paling relevan untuk menstranformasikan nilai-nilai pendidikan multicultural kepada peserta didik.

Hidup itu sangat penting untuk mendapatkan suatu yang berharga di akhir hayat nanti, maka Agama telah menggariskan suatu sistim yang amat 
sempurna dari prinsip-prinsip yang mempertunjukkan kepada manusia bagaimana caranya menjalani hidup ini sebaik-baiknya, apa yang harus dikerjakan dan apa yang harus ditinggalkan, apa yang harus diambil dan apa yang harus dihindarkan. Seluruh manusia datang dari Tuhan dan tidak ada keraguan sedikit pun bahwa mereka semuanya akan kembali kepada-Nya.

\section{PEMBAHASAN}

Dalam pembahasan yang berkaitan dengan pola interaksi siswa pihak sekolah telah menggunakan metode sebagai berikut : PAKSA (Pray, Attitude, Knowledge, Skill, Action). Adanya siswa siswi yang mempunyai perbedaan agama yang diyakininya sebagai pegangan hidup yang telah dibawa dari masingmasing daerahnya.

Gagasan Perbedaan $\begin{aligned} & \text { Agama } \\ & \text { tentang bagaimana } \\ & \text { mengarahkan perilaku individu }\end{aligned}$
menjadi perilaku kelompok agaknya
bisa dikonfirmasi dengan realitas
interaksi sosial aksi interaksi yang
ada di lapangan.

Pray : Berdoa atau memohon, menurut pandangan Agama Islam :
(Indriati, Korina dalam HAM dan Pluralisme Agama). Agama dalam kehidupan masyarakat majemuk dapat berperan sebagai faktor pemersatu (integratif) namun dapat juga berperan sebagai faktor pemecah (disintegratif). Fenomena ini banyak ditentukan oleh empat hal: (a) Teologi agama dan doktrin ajarannya, (b) Sikap dan perilaku pemeluknya dalam memahami dan menghayati agama tersebut, (c) Lingkungan sosio-kultural yang mengelilinginya, dan (d) Peranan dan pengaruh pemuka agama tersebut dalam mengarahkan pengikutnya.

Pada waktu awal-awal di Madinah, maka langkah pertama yang dilakukan oleh Nabi Muhammad SAW adalah menyatukan masyarakat di Madinah dan sekitarnya, yang terdiri dari beberapa suku dan agama. Langkah strategis ini yang melahirkan "Piagam Madinah" yang meletakkan dasar-dasar kehidupan berbangsa dan bernegara bagi masyarakat majemuk. Dalam Piagam Madinah tersebut diatur hubungan antara sesama anggota komunitas Islam, dan antara anggota komunitas Non Muslim interaksi antara siswa juga didukung oleh tokoh-tokoh yang mempunyai 
kepercayaan agama hindu ;

Hyang Widi atau Tuhan Yang Maha Esa sebagai sumber kehidupan dan penghidupan manusia menciptakan alam semesta raya dengan segala isinya (makro kosmos dan micro kosmos) seperti disebutkan di dalam Manawa Dharmacastra, Bab I sloka 6, sebagai berikut :

Tatah swayambhurbhagawan, Awyakto' wyanjayannidham, mahabhutadi wrttaujah, pradurasitta manudah.

Sloka di atas mempunyai arti sebagai berikut:

Kemudian dengan kekuatan tapaNya, la, Yang Mafia Ada, menciptakan isi, Mahabhuta (unsur alam semesta) dan lain-lainnya, nyata terlihat melenyapkan alam kegelapan (Pudja dan Sudharta, 1973:31)

Adapun maksud dari sloka di atas adalah: Hyang Widi menciptakan alam semesta raya ini dari unsurunsur Panca Mahabhuta yang terdiri dari unsur akasa (ether), unsur yeja (cahaya), unsur bayu (hawa), unsur apah (air) dan unsur pertiwi (tanah). Panca Mahabhuta ini berasal dari Beliau sendiri dan panas (energi) yang digunakan untuk memanasi kelima unsur Mahabhuta itu juga berasal dari Beliau sendiri.

Kendati pun Bhuwana Agung dan Bhuwana Alit itu telah terwujud yang mengakibatkan alam semesta raya termasuk bumi yang kita tempati menjadi terang benderang, Ternyata Hyang Widi tiada henti-hentinya bekerja untuk memelihara alam semesta raya dengan segala isinya. Hal ini dapat kita lihat di dalam Bhagawad Gita, Bab III, sloka yang berbunyi sebagai berikut:

Utsideyur ime loka, ma karyam karma ced aham, samkarasya ca karta syam, upahanyam imah prajah.

Sloka di atas mempunyai arti kurang lebih sebagai berikut:

Jika Aku berhenti bekerja, maka ketiga dunia ini akan hancur lebur dan Aku akan menjadi pencipta dari penghidupan yang tak teratur dan Aku akan merusak rakyat ini. Hyang Widi tidak henti-hentinya menjaga dan memelihara alam semesta raya ini (dunia) ini, menjaga dari keruntuhan dan kemusnahan (Mantara, 1976:57)

Secara harfiah Tri Hita Karana berari juga tiga penyebab kesejahteraan. Istilah Tri Hita Karana berasal dari kata: Tri, berarti tiga; 
Hita berarti sejahtera dan Karana berarti penyebab. Pada hakekatnya Tri Hita Karana mengandung pengertian, bahwa ketiga penyebab kesejahteraan itu bersumber kepada keselarasan hubungan antara: (1) Manusia dengan Hyang Jagad karana atau Tuhan Yang Maha Esa, (2) Manusia dengan alam lingkungannya, (3) Manusia dengan sesamanya dan masyarakatnya.

Unsur-unsur Tri Hita Karana dapat ditemukan dalam Bhagawad Gita, Bab III, sloka 10 yang berbunyi sebagai berikut:

Sahayajnah prajah srstva,

puro vaca prajaptih,

anena prasavisyadhvam,

esa vo sty istakamadhuk

Sloka mengandung arti kurang lebih sebagai berikut:

Pada jaman dahulu kala Prajapahit menciptakan manusia dengan yadnya dan bersabda: Dengan ini engkau akan mengembang dan akan menjadi Khamaduk, dari keinginanmu. Khamaduk adalah seekor sapi milik Dewa Indra yang dapat memenuhi semua keinginan (Mantra, 1967:51).

Apabila dikaji lebih lanjut isi sloka 10 ini, maka akan ditemukan unsur-unsur Tri Hita Karana itu sebagai berikut: (1) Prajapati ialah Brahma sebagai Yang Maha Pencipta, (2) Praja, berarti rakyat, orang-orang, manusia, (3) Kamadhuk ialah seekor sapi milik Dewa Indra yang dapat memenuhi semua keinginan manusia. Sebenarnya pengertian Khamaduk ini merupakan simbol dari dunia kita ini, yakni Ibu kertiwi yang telah menyediakan berbagai sumber daya alam, seperti bumi, air dan segala kekayaan alam yang terkandung di dalamnya, termasuk juga udara. Semuanya ini dapat memenuhi keinginan dan hajat hidup semua makhluk ciptaan Sang Hyang Jagadkarana, terlebih-lebih bagi manusia sebagai mahkluk yang berakal. Sang Hyang Jagadkarana telah menyediakan Kamadhuk itu bagi manusia dan Beliau pun telah memberikan akal kepada manusia agar dapat memanfaatkan Kamadhuk itu sebesar-besarnya. Di sini terlihat, bahwa Sang Hyang Jagadkarana memberikan hak kepada manusia untuk memanfaatkan bumi, air dan kekayaan alam yang terkandung di dalamnya selanjutnya menurut pandangan tokoh dari agama Buddha yang berkaitan dengan interaksi sosial antar siswa di pendidikan 
multicultural sebagai berikut :

Sang Buddha Gotama mangkat saat usia 80 tahun di bulan Waisak Purnama Sidhi tahun 543 SM. Tiga bulan sebelum mangkat, Sang Buddha telah memberitahukan kepada para siswanya. Kemudian ada siswa yang bertanya, "Apakah masih ada Dhamma yang belum diajarkan oleh Sang Buddha kepada para siswanya? Sedang tiga bulan lagi Sang Buddha mangkat kepada para siswa, setelah Sang Buddha mangkat, siapakah yang akan meneruskan ajaran Sang Buddha? Jawaban Sang Buddha ada hubungannya dengan pluralisme agama. Sabda Sang Buddha demikian, "Dhamma yang saya ajarkan sebanyak dedaunan yang saya genggam, di dunia ini masih banyak Dhamma, sebanyak dedaunan yang ada di hutan". Tetapi semua Dhamma harus berdasar Ketuhanan dan mengajarkan sifatsifat luhur: cinta kasih, kasih sayang, simpati dan keseimbangan batin yang tak tergoyahkan. Ajaran yang tidak berdasar Ketuhanan dan tidak mengajarkan sifat-sifat luhur itu bukan Dhamma.

Dhamma lebih luas kalau dibandingkan dengan ajaran agama dan semua ajaran disebut Dhamma. Dhamma adalah segala sesuatu yang dapat membawa pada kemerosotan hidup atau membawa kesengsaraan hidup. Sehingga dapat kita rumuskan Dhamma adalah segala sesuatu yang dapat membawa kita hidup bahagia. Semua ajaran agama adalah Dhamma sehingga dapat disimpulkan bahwa semua ajaran agama dapat membawa kebahagiaan hidup bagi manusia yang percaya dan meyakini kebenaran ajaran agamanya.

Buddha bukan nama orang, melainkan tingkat kesucian tinggi yang dapat dicapai oleh manusia. Buddha bukan monopoli seseorang dan bukan monopoli umat Buddha, siapa saja, apapun keyakinannya, mernperoleh kesempatan yang sama untuk mencapai tingkat kesucian tinggi atau tingkat kebuddhaan.

Sabda Sang Buddha Gotama tentang ajaran para Buddha adalah demikian:

a. Janganlah berbuat kejahatan $=$ Sabba papassa akaranam

b. Tambahlah kebajikan $=$ Kusalassa upasambada

c. Sucikan hati dan pikiran $=$ Sacillapariyo dapanam 
Ajaran para Buddha ini bersifat universal, semua ajaran agama berintikan ajaran para Buddha tersebut. Berawal dari kesamaan ajaran yang universal tersebut, kita dapat mengatakan bahwa semua Dhamma atau ajaran agama dapat membawa kebahagiaan hidup bagi manusia yang percaya dan meyakini kebenarannya. Demikian pula untuk semua ajaran agama, masing-masing merupakan satu disiplin ajaran yang utuh atau bulat, dapat membawa kebahagiaan hidup bagi manusia yang percaya dan meyakini kebenarannya seterusnya menurut pandangana tokoh yang mempunyai keyakinan Kristen protestan tentang interaksi sosial antar siswa di pendidikan siswa multikultural sebagai berikut :

Pluralisme Agama menjadi penting karena memang bagi suatu bangsa untuk menjamin persatuan dan kesatuan bangsa, maka kemajemukan agama sebagai salah satu aspek kemajemukan yang dipunyai bangsa jelas merupakan faktor strategis yang harus dikelola secara arif dan bijaksana agar tidak sampai menggoyahkan ketahanan nasional bangsa. Bukankah bangsa Indonesia diusahakan sebagai bangsa yang religius? Oleh sebab itu menurut pandangan saya apapun yang kita bicarakan yang menyangkut kelanjutan hidup bangsa ini, haruskah dibicarakan dalam kaitan dengan hasrat dan aspirasi keagamaan bangsa Indonesia. Ini berupa suatu conditio sine quanon. Oleh sebab itu isu HAM pun bagi bangsa Indonesia haruslah dikaitkan dengan hasrat dan aspirasi keagamaan bangsa. Hal-hal inilah yang ingin saya kemukakan di sini, sebagaimana yang tertera di bawah.

Jadi, menurut Luf, hak manusia yang berasal dari hak Tuhan terkait erat dengan peningkatan harkat dan martabat manusia (human dignity). Karena Tuhan itu berkarya dan mensejahterakan (shalom: damai sejahtera), maka hak yang diperoleh manusia itu termasuk juga hak untuk berkarya, membangun dan memperoleh kesejahteraan spiritual dan material. Menurut Luf, pandangan ini mempunyai kemiripan dengan pandangan Agama tentang manusia yang diciptakan Tuhan sebagai khalifatullah fil ardhi, sebagai pengganti Tuhan di dunia. Sebagai khalifah atau pengganti Allah, manusia memperoleh kemerdekaan dari pihak Tuhan untuk 
memberlakukan perintah untuk mencapai dunia yang baik dan diampuni Allah.

Atas nama agama peperangan yang seringkali tidak adil telah dikobarkan kebebasan untuk berfikir dan mengemukakan pendapat telah ditindas, usaha untuk mendapatkan ilmu pengetahuan selalu dihalanghalangi, kebenaran yang dikemukakan seseorang dengan berani ditolak, kejujuran dan kemuliaan diabaikan. Dan dengan mengatas namakan agama, kejahatan telah menindas manusia. Akhirnya agama itu sendiri digunakan secara tidak langsung untuk menindas ummat manusia.

Semua itu adalah kenyataan sejarah, yang mana tak seorang pun dapat mengingkarinya. Tapi, apakah ini merupakan fungsi dari agama itu sendiri, atau apakah itu merupakan suatu pendekatan yang benar terhadap suatu agama? Bisakah semua ini menjadi maksud dari agama? Jawaban yang tepat tentulah akan menjawabnya tidak. Di dunia ini terdapat banyak agama. Dan tiap agama akan mengatakan bahwa hanya yang satu itulah agama yang benar. Tiap agama akan menyatakan hanya ialah teologi yang datang dari Tuhan, untuk membimbing manusia kepada jalan yang benar. Tiap pemeluk suatu agama akan menyatakan bahwa hanya agama merekalah satu-satunya agama yang benar.

Tapi perlu diketahui, bahwa tiap pendapat itu saling bertentangan antara yang satu dengan yang lainnya. Hal ini akan membuat bingung orangorang, yang kemudian mengambil suatu tindakan kemanusiaan dengan menciptakan hubungan persaudaraan yang universal, dibawah lindungan Tuhan Penguasa alam semesta, yang pengasih dan Penyayang. Keadaan seperti ini membuat orang-orang (yang berprinsip netral dalam menyelidiki salah satu agama) semakin bingung, sehingga mereka akhirnya ragu untuk memeluk suatu agama.

Keyakinan Ketuhanan adalah tunggal dan khusus dalam bentuk pemikiran yang amat luas. Memang benar bahwa agama itu harus datang dari Tuhan sebagai pembimbing bagi manusia untuk menuju kepada jalan yang benar, ini sejalan dengan kebutuhan manusia sepanjang masa. Hal ini kemudian akan menjurus pada suatu kesimpulan 
Dengan berpegang kepada prinsip ini, Keyakinan Ketuhanan tidak hanya suatu agama yang penuh dengan kewajiban-kewajiban spiritual (rohani) dan intelektual (kecerdasan) tapi ia juga penuh dengan hal-hal yang dapat memenuhi kebutuhan sosial ummat manusia. Dia tidak akan membingungkan manusia melainkan akan membimbingnya kepada jalan yang lurus dan benar. Dia tidak akan merendahkan derajat manusia, melainkan mempertinggi dan memperkaya moralnya. Dia tidak akan menjauhkan manusia dari halhal yang baik dan mencelakakannya, melainkan akan memperlihatkan kepada mereka kekayaan pemikiran dan kebenaran perbuatan. Dia tidak akan menyempitkan ruang lingkup berfikir mereka, melainkan akan memperluas pandangan mereka terhadap apa yang disebut dengan kebenaran dan kebaikan. Ringkasnya, suatu agama yang benar itu adalah agama yang dapat mendekatkan dan memperkenalkan manusia kepada Tuhan sebagaimana ia dekat dan kenal dengan dirinya sendiri. Demikianlah pengertian yang sebenarnya.

Apabila maksud-maksud yang benar dari suatu agama dapat diuji kebenarannya, maka agama itu akan dapat memuaskan pengikutnya baik dari segi spiritual maupun material kebendaan. Dia akan dapat memecah segala persoalan ummat manusia dan kemudian menyempurnakannya, dia akan menyempurnakan pemikiran manusia, dan akan menuntutnya kepada jalan yang benar dan hidup yang baik. Dia akan memperluas ilmu pengetahuannya tentang ketuhanan. Dia akan menunjukkan rahasiarahasia kehidupan, dan tentang yang baik dan yang tidak baik (jahat). Dia akan melindungi manusia dari kesalahan, akan melepaskan akal fikiran mereka dari pertentangan, akan memperkuat karakter (akhlak) mereka. Semua ini akan bisa diterima hanya bila manusia itu berfikir tentang kewajiban-kewajiban spiritual dan peraturan-peraturan yang nyata, yang telah diperkenalkan oleh agama.

Di samping itu, agama yang benar akan mendidik manusia dan akan melatih mereka untuk bersabar dalam membawa mereka kepada kebenaran dan kebajikan, untuk mencintai yang benar dan yang baik. Lebih jauh, agama yang benar itu selalu mendorong manusia untuk 
menentang segala bentuk kejahatan, dan mendorong mereka untuk terus menerus mencari keridhoan dan pertolongan Allah. Ia akan melengkapi manusia perdamaian dan tenteram, yang membuat hidup mereka bahagia dan penuh arti.

Hal itulah yang menyebabkan mengapa suatu agama yang benar bisa berbuat apa saja demi kepentingan dan kebaikan manusia. Dan itulah sebenarnya dari Keyakinan Ketuhanan. Agama manapun yang bertentangan dengan konsep jelaslah bukan Agama dan ini menolak pendapat bahwa cara hidup multikultural merupakan sumber konflik sperti yang dijelaskan di atas pembahasan. Maka dalam pembahasan interaksi sosial yang berkaitan dengan teori interaksi sosial Max Webber patut untuk didukung sebagai ground theory.

Attitude : Sikap, corak pikiran, para siswa diarahkan kebebasan berfikir sebagai suatu nilai yang patut dihargai serta tidak dapat ditentang oleh berbagai individu, kelompok dan bangsa. Tetapi sering salah mengertikan. Sesungguhnya amat jelas, bahwa tidak ada seorang manusia pun dalam kelompok masyarakat, dapat bebas dengan pengertian sebebas-bebasnya. Ada garis-garis yang harus dilalui dan dipatuhi oleh seseorang terhadap orang lain dalam kelompok masyarakat, jika masyarakat itu ingin berfungsi bebas sebagaimana mestinya.

Kebebasan itu secara umum mendapat tempat yang baik di dalam kehidupan. Agama senantiasa mengajarkan kebebasan, dan menghargai kebebasan sangat tinggi. Kebebasan sangat tinggi. Kebebasan seseorang muslim dalam Agama sama dengan kebebasan yang dimiliki oleh orang yang bukan muslim. Kebebasan dalam Agama mencakup seluruh bidang dan kegiatan manusia. Sebagaimana juga telah dijelaskan, setiap manusia adalah bebas menurut nya. Berarti bahwa manusia itu dilahirkan bebas dari perbudakan, dosa, kesalahan pembawaan dan warisan leluhurnya. Kebebasannya dari pada dosa tetap dihormati sampai ia melakukan pelanggaran terhadap ketentuan Tuhan dan ketentuan manusia ( ketentuan bermasyarakat ).

Salah satu ketentuan dasar dari Agama adalah pembebasan fikiran dari pada keragu-raguan, pembebasan 
jiwa dari dosa, pembebasan diri dari penindasan dan rasa takut, dan pembebasan segala-galanya dari kekacauan dan kemerosotan.

Pandangan hidup ummat Agama adalah untuk merealisasikan usaha mendalami kegiatan intelektual, memantapkan hati dalam memahami persoalan spiritual, menegakkan prinsip moral, dan bahkan juga untuk menciptakan suatu peraturan. Bila seorang ummat manusia selalu mengikuti petunjuk yang telah ditetapkan ini, dia tidak akan pernah mengalami kegagalan dalam mencapai tujuan pokoknya yang paling tinggi dari kebebasan dan emansipasi.

Pertanyaan, tentang kebebasan keyakinan, ibadah, dan getaran hatinya dalam mengingat Tuhan adalah yang cukup penting bagi penganut agama. Setiap manusia berhak mencari dalam masalah keyakinan, kesadaran dan ibadah (penyembahan).

Agama mengambil sikap seperti ini, karena agama tidak bisa dilepaskan dari iman, kehendak, dan tawakkal. Semuanya ini tidak akan berarti seandainya dilakukan dengan paksaan. Agama telah menjelaskan kebenaran yang berasal dari Tuhan dan memberi kebebasan untuk memilih keputusannya sendiri.

Kebebasan dalam Agama merupakan suatu bagian dari iman, sebagai perintah yang baik dari Allah. Konsep itu dibangun atas prinsipprinsip yang fundamental sebagai berikut :

Pertama, manusia menyadari, bahwa yang harus ia patuhi hanya Allah, kepada-Nyalah setiap manusia mempertanggung-jawabkan dirinya.

Kedua, setiap manusia secara pribadi bertanggung jawab atas segala perbuatannya dan dengan sendirinya ia mengambil buah dari apa yang ia kerjakan.

Ketiga, Tuhan memberi kuasa kepada manusia untuk mempersiapkan segala sesuatu bagi dirinya, atas apa-apa yang harus ia pertanggung jawabkan.

Keempat, manusia secara penuh dilengkapi Tuhan dengan bimbingan spiritual rohaniah dan kemampuan berfikir, yang memungkinkan baginya untuk memikul suatu tanggungjawab dalam menentukan pilihannya sendiri.

Semua itu adalah pondasi yang amat kokoh dari kebebasan dalam Islam. Ia merupakan kebenaran 
alamiah yang selalu dimiliki manusia, suatu keistimewaan spiritual, suatu hak luar biasa manusia tentang moral; dan seluruhnya merupakan suatu kewajiban religius . Masalah konsep kebebasan dalam Agama ini, sama sekali tak ada tempat bagi agama untuk merintangi, konflik yang ditimbulkan oleh perbedaan tinggi rendah derajat manusia, atau pertentangan - pertentangan rasial. Hak-hak individu dari kebebasan adalah bersih sebagaimana haknya untuk hidup; kebebasan adalah sama dengan hidup itu sendiri.

Sebuah elemen dasar dalam sistim-sistim yang amat berharga dalam Keyakinan BerTuhan adalah prinsip-prinsip persamaan, atau lebih baik disebut dengan prinsip-prinsip keadilan. Persamaan di sini tidak bisa dikacaukan atau dicampur adukkan dengan pengertian yang identik (persis sama) atau stereotip (klise). Agama mengajarkan hal itu karena dalam pandangan Tuhan semua manusia sama, tapi tidak dalam pengertian identik. Perbedaanperbedaan tetap ada, misalnya perbedaan dalam masalah kemampuan, potensi, ambisi, kekayaan dan seterusnya. Tapi perbe- daan ini dengan sendirinya tidaklah dapat dikatakan yang akan menentukan tinggi rendahnya derajat manusia. Keturunan, warna kulit, harta benda, dan prestasi yang dapat dicapai seseorang, semuanya bagi Tuhan tidaklah membedakan manusia dengan manusia yang lain. Bagi Tuhan manusia itu hanya berbeda dari segi ketaqwaannya kepada Allah.

Perbedaan ras, warna kulit, atau status sosial, sifatnya adalah aksidental (kebetulan). Semua itu tidaklah membedakan status dan tinggi rendah derajat manusia di sisi Allah. Selanjutnya, keistimewaan persamaan tidaklah merupakan suatu hak yang konstitusional, atau persetujuan-persetujuan yang ikhlas, atau kedermawanan seseorang saja. Hal ini merupakan bagian dari iman yang ditanggapi sangat serius oleh ummat Islam. Dasar yang sangat kuat dari konsep persamaan dalam Agama ini sangat dalam terhunjam dalam pandangan Islam. Hal itu terikat kepada beberapa prinsip dasar sebagaimana di bawah ini:

1. Seluruh manusia diciptakan Tuhan Yang Satu, Yang Esa, Yang Maha Kuasa semesta alam. 
2. Seluruh manusia memiliki ras dan golongan dan mereka semuanya sama dalam satu keturunan, yaitu dari Adam dan Hawa.

3. Tuhan sangat adil dan sangat sayang kepada seluruh makhluq ciptaan-Nya. Dia tidak pernah memihak kepada suatu golongan, umur (besar kecilnya manusia), dan kebudayaan.

4. Seluruh manusia dilahirkan sama dengan yang lain, tidak membawa harta kekayaan apapun juga. Seandainya dia mati, maka juga ia tak dapat membawa harta benda yang ia miliki.

5. Tuhan memberikan imbalan kepada seseorang setimpal dengan apa yang telah ia usahakan dan apa yang telah ia kerjakan.

6. Tuhan memberikan anugerah yang tinggi kepada manusia, dengan kehormatan dan kemuliaan.

Semua itu adalah beberapa prinsip persamaan yang ada dalam Islam. Apabila konsep ini dijalankan sepenuhnya maka ia tidak akan memberikan adanya tempat bagi ketidak adilan dan kekacauan. Dan bila ajaran yang benar ini diterapkan, maka tidak akan ada tempat bagi penindasan dan penekanan. Bangsa pilihan (seperti penilaian orang Yahudi) dan konsep masyarakat yang tidak berbangsa akan terbuang jauh bila konsep yang disebutkan di atas itu diterapkan, sebagaimana juga adanya kasta tertinggi dan kasta dari golongan kedua dari masyarakat, akan tidak berarti dan akan ditolak.

Sebuah elemen yang fundamental dalam sistim Agama adalah nilai persaudaraan ummat manusia. Nilai-nilai ini juga ditegakkan atas beberapa prinsip yang sama, yang telah dibicarakan dalam hubungannya dengan kebebasan dan persamaan. Di samping prinsipprinsip yang telah dikemukakan di atas itu, persaudaraan antar ummat manusia di dalam Agama didasari atas kepercayaan yang tidak dapat diragukan lagi terhadap ke Esaan Tuhan dan penyembahan kepada-Nya yang sangat universal, kesatuan ummat manusia sebagai abdi Allah, kesatuan upacara penyembahan melalui agama.

Bagi ummat Islam, Tuhan 
hanya satu, Yang Abadi dan Umum. Dia adalah Pencipta seluruh manusia, yang akhir dari segala yang akhir, yang menentukan nasib dari seluruh alam ini. Pencipta dari seluruh alam ini adalah Tuhan sendiri. Asal usul manusia adalah dari Adam dan Hawa. Terhadap yang menentukan nasib, tak seorangpun dari ummat Agama yang ragu bahwa hanya Tuhan yang menentukan, Dia adalah Pencipta seluruh alam ini, dan kepada-Nyalah seluruh manusia ini akan kembali.

Apabila hal ini ditafsirkan lebih luas, tak akan terdapat yang disebut dengan keunggulan atau kelebihan seseorang dari orang yang lain. Bila hal ini sampai kepada akal dan pemikiran manusia, maka ia akan memperlihatkan kepada manusia itu sesuatu yang jelas dan tentang persaudaraan ummat manusia. Karena ummat Agama percaya kepada keEsaan Allah, kesatuan ummat manusia, sebagaimana ia percaya kepada seluruh nabi dan rasul, tanpa adanya perbedaan atau diskriminasi antara satu dengan yang lain.

Untuk menerangkan bagaimana Agama menjawab pertanyaanpertanyaan tentang perdamaian, seseorang cukup dengan menerangkan beberapa kenyataan dan fakta yang terdapat dalam agama. Perdamaian dan Agamaadalah berasal dari satu akar yang sama dan selanjutnya boleh juga disebut bahwa Agama adalah sinonim dari perdamaian. Salah satu dari sekian banyak nama Tuhan adalah Damai. Kesimpulan setiap kata yang diucapkan Ummat Agama dalam setiap shalatnya (sembahyang) adalah kata-kata perdamaian. Ucapan pertama (salam) yang diucapkan oleh ummat Agama ketika ia selesai menghadap Tuhan adalah perdamaian. Salam dan ucapan sehari-hari yang diucapkan oleh ummat Agama ketika saling bertemu adalah ucapan perdamaian. Kata sifat dari "Muslim" artinya : adalah perdamaian. Surga dalam Agama adalah suatu tempat yang damai.

Hal ini memperlihatkan betapa mendasar dan kuatnya pengertian perdamaian dalam agama. Setiap orang yang mencari Tuhan melalui agama, sama sekali ia tidak akan kecewa untuk mendapatkan kedamaian bersama Tuhannya, damai dengan dirinya sendiri, dan damai bersama orang-orang yang mau mengikuti-Nya. Berpegang kepada 
pengertian ini akan menempatkan manusia pada tempat yang paling mulia di dunia ini, dan menjalani hidup ini dalam kenyataan-kenyataan perdamaian, maka manusia yang telah mendapatkan jalan yang benar dan berprinsip tidak akan gagal untuk hidup di dunia ini lebih baik, untuk mendapatkan kemuliaan manusia, untuk memperoleh persamaan antara satu dengan yang lain, untuk menikmati rasa persaudaraan yang universal, dan untuk menciptakan perdamaian yang abadi.

Kata kemasyarakatan memiliki beberapa konotasi tertentu. Sebagian dari padanya adalah bersifat romantis dan penuh kerinduan), dan sebagian lagi adalah (kemunduran dan kekolotan. Tapi, untuk melakukan hal-hal tertentu yang paling mendasar, sebenarnya telah dapat dibatasi pembahasan terhadap pengertian yang paling fundamental dari kata community atau kemasyarakatan, dalam beberapa dasar. Dasar pertama, kemasyarakatan itu berarti: Seluruh bentuk hubungan yang diatur oleh keakraban yang tinggi dan seseorang dalam pergaulannya dengan orang lain, kedalaman perasaan, ketentuan-ketentuan moral, hubungan sosial yang terus menerus berkelanjutan. Hal itu semua didapatkan dalam suatu wilayah, agama, bangsa, suku bangsa, atau ras dan lain-lain. Hal itu merupakan bentuk awal bagi terciptanya suatu keluarga.

Dasar kedua, suatu masyarakat adalah suatu kelompok yang mencakup/meliputi dua karakter tertentu karakter tertentu.

1. Kelompok yang didalamnya terdapat individu-individu yang dapat memiliki sebagian besar kegiatan dan berbagai pengalaman yang sangat berguna baginya.

2. Kelompok dimana orang yang berada didalamnya terikat oleh tanggung jawab dan oleh identitas bersama.

Dalam perjalanan sejarah, pengertian di atas berkembang dari hubungan akrab, hubungan sosial yang mendalam, pertalian-pertalian moral dari masyarakat, menuju suatu bentuk yang tidak terlalu bersifat pribadi, dan berbagai ikatan itu. Dan pergeseran ini diatur oleh beberapa fase yang berbeda-beda dan ditandai oleh konsekuensi yang sukar dicapai.

Dari pengertian historis itu akan 
dapat diambil suatu kesimpulan; Pertama, evolusi (perkembangan) historis tidak negatif secara keseluruhan atau positif semuanya, dan konstruktif. Konsekwensi itu (positif dan negatif) telah mempengaruhi masyarakat yang berbeda-beda tingkatannya. Kedua, masyarakat modern itu jauh dari kesempurnaan, sebab banyak lagi halhal yang harus dibentuk. Ketiga, keadaan masyarakat bukanlah tidak diakibatkan oleh suatu sebab tertentu dan bukan pula tidak membutuhkan berbagai harapan. Sebenarnya, terdapat banyak krisis dan kesusahan yang harus ditanggulangi, tapi harus disadari suasana seperti itu bukan tidak bisa dikontrol dan dikendalikan. Akhirnya manusia tumbuh saling memiliki perasaan tergantung antara satu dengan yang lain, dan selanjutnya mereka berusaha untuk menjalin hubungan baik.

$\begin{array}{lrr}\begin{array}{l}\text { Secara } \\ \text { umum }\end{array} & \text { hendaklah } \\ \text { diperhatikan } & \text { bahwa } & \text { konsep } \\ \text { kemasyarakatan dalam } & \text { Agama } \\ \text { mempunyai bentuk } & \text { (karakter) } \\ \text { tertentu. Semua itu bisa dilihat dari } \\ \text { dasar-dasar kemasyarakatan, dalam } \\ \text { misi dan maksud historisnya } \\ \text { (sebagaimana dalam sejarah), status }\end{array}$

masyarakatnya identitas dan kesinambungannya.

Masyarakat dalam Agama tidak didasari atas suku (ras) kebangsaan, pekerjaan, kekeluargaan atau atas dasar kepentingan-kepentingan khusus, Masyarakat dalam Agama tidak menurut nama pimpinannya atau orang yang mendirikannya. la lebih sempurna dari pengertian nasional dan Kemasyarakatan dalam Agama adalah prinsip yang telah diatur dan ditentukan Tuhan Swt, agar semua manusia yakin kepada-Nya, patuh kepada hukum-hukum-Nya, dan menyerah kepada kehendak-Nya. Ringkasnya, masyarakat Agama itu ada jika masyarakat tunduk dan patuh kepada ajaran Islam. Masyarakat Agama mempunyai sejarah yang tidak hanya untuk mempertahankan kelangsungan hidupnya atau kekuasaan, keturunan, dan kelanjutan psikologisnya kejiwaan saja.

Peranan sejarah yang terlihat dari masyarakat agama adalah bentuk kebaikan, kesehatan dan kemuliaan. Masyarakat agama yang sebenarnya adalah pelindung yang sangat kuat bagi kebaikan dan tegas terhadap musuh yang jahat.

Apa-apa yang dikehendaki oleh 
masyarakat umumnya, merupakan hal-hal yang diingini oleh perorangan. Sebab, suatu masyarakat secara keseluruhan merupakan satu kesatuan organik di mana setiap individu akan mempertanggungjawabkan semua tindakannya di hadapan Allah, peraturan yang harus dilalui oleh seorang muslim adalah sebagaimana yang telah dijelaskan oleh rasul-Nya.

Maksudnya ialah agar masyarakat dalam Agama hendaklah menjadi contoh bagi yang lain. Seorang muslim hendaklah jadi pedoman bagi yang lain dan tindakannya hendaklah merupakan hal-hal yang dapat diteladani golongan lain. Untuk itu, harus dihindari hal-hal yang bertentangan dan tidak cocok dengan apa-apa yang telah digariskan oleh ajaran Islam. Ummat Agama hendaklah menghindari tindakan yang setengahsetengah, harus teguh hati dan bekerja keras dalam setiap usaha, mengetahui apa yang harus diterima dan apa yang harus ditolak, dan selanjutnya ummat Agama hendaklah memiliki prinsipprisip yang kuat sehingga dapat menyesuaikan diri dan mendapatkan tempat dalam pergaulan lnilah bentuk masyarakat Agama yang amat berse- jarah. Dan merupakan kriteria ummat Agama atau masyarakat Agama yang paling baik diantara golongan masyarakat lainnya.

Identitas masyarakat Agama itu terletak pada prinsip keseimbangan yang tetap, tingkah laku yang terpuji, pandangan hidup yang sama, memiliki sifat tenggang rasa solidaritas dan keadilan.

Untuk mengatur kelanjutan dari masyarakat Agama itu, ada beberapa persoalan yang perlu diperhatikan. Inilah kewajiban ummat Agama untuk melakukan dan memajukan atau meneruskan kelanjutan itu. Antara lain bisa disebutkan seperti : undang-undang perkawinan dan warisan, kewajiban untuk mengeluarkan zakat dan menunaikan ibadah haji, kebaikan yang saling memberi dan hubungan kekeluargaan yang akrab, kesadaran individu dan undang-undang pemilikan sosial. Semua itu berorientasi pada kontinuitas yang sahat dari suatu masyarakat Islam. Disamping itu, Tuhan selalu melindungi kelanjutan masyarakat Agama dengan berbagai jalan.

Knowledge: Pengetahuan. Seperti diketahui, perintah Allah 
SWT, pertama kepada Muhammad SAW, yaitu perintah iqra' atau membaca, menunjukkan bahwa seorang muslim harus bisa membaca perintah-perintah Allah di dalam AlQur'an sebagai kitab suci dan di dalam alam semesta sebagai kitab besar ciptaan-Nya. Itulah sebabnya, peradaban Islam merupakan peradaban pertama yang mengintegrasikan empirisitas pada kehidupan keilmuan dan keagamaan secara terpadu. Sebagai dampak kesepaduan ilmu dan agama ini, peradaban Islam mencatat kebangkitan peradaban yang menghasilkan penemuan-penemuan ilmiah yang luar biasa selama tujuh abad kurun pemerintahan Daulah Umayyah, Daulah 'Abbassiyyah, dan Daulah Fathimiyyah.

Namun, untunglah pada milenium ketiga ini beberapa institut agama Islam negeri telah diitegrasikan kembali dengan ilmuilmu umum. Sayang, umumnya penyatuan ini hanya pada tataran institusional tanpa implementasi di bidang konsepsional dan operasional sebagai pengaruh warisan pemikiran dikotomis yang dianut oleh pemerintah nasional yang pada gilirannya diwariskan dari pemerintah kolonial para penjajah. Oleh sebab itu, model integrasi agama dan sains dan implementasinya dapat dijadikan pegangan dalam pendidikan siswa multikultural karena didalamnya ada beberapa faktor yang relevan dengan ground theorynya.

Telah banyak model yang diajukan orang untuk reintegrasi sains dan agama. Model-model itu dapat diklasifikasi dengan menghitung jumlah konsep dasar yang menjadi komponen utama model itu. Jika hanya ada satu, model itu disebut model monadik. Jika ada dua, tiga, empat, atau lima komponen, modelmodel itu masing-masingnya bisa disebut sebagai model-model diadik, triadik, tetradik, dan pentadik. Berikut ini akan dibahas secara singkat masing-masing model tersebut.

Varian kedua dari model diadik ini mungkin dapat dinyatakan oleh gambar sebuah lingkaran yang terbagi oleh sebuah garis lengkung menjadi dua bagian yang sama luasnya, seperti pada simbol dari Tao dalam tradisi Cina. Berbeda dengan model independensi, dalam model kedua, sains dan agama adalah sebuah kesatuan yang tak tepisahkan. 
Barangkali, ini dapat dipahami dengan menyimak pandangan Fritjof Capra: "sains tak membutuhkan mistisisme dan mistisisme tak membutuhkan sains. Akan tetapi, manusia membutuhkan keduanya". Model ini adalah model diadik komplementer.

Varian ketiga mungkin dapat dilukiskan secara diagram dengan dua buah lingkaran sama besar yang saling berpotongan. Jika kedua lingkaran itu mencerminkan sains dan agama, akan terdapat sebuah kesamaan. Kesamaan itulah yang merupakan bahan bagi dialog antara sains dan agama. Misalnya, Maurice Buccaille menemukan sejumlah fakta ilmiah di dalam kitab suci Al-Quran. Atau para ilmuwan yang menemukan sebuah bagian pada otak yang disebut sebagai "the God spot" yang dipandang sebagai pusat kesadaran religius manusia. Model ini dapat disebut sebagai model diadik dialogis.

Model ketiga adalah model triadik sebagai suatu koreksi terhadap model diadik independen. Dalam model triadik ada unsur ketiga yang menjembatani sains dan agama. Jembatan itu adalah filsafat. Model ini diajukan oleh kaum teosofis yang bersemboyankan "There is no religion higher than Truth". Kebenaran atau "Truth" adalah kesamaan antara sains, filsafat, dan agama.

Tampaknya, model ini merupakan perluasan saja dari model diadik komplementer dengan memasukkan filsafat sebagai komponen ketiga yang letaknya di antara sains dan agama. Model triadik komplementer ini mungkin dapat dimodifikasi dengan menggantikan filsafat dengan humaniora atau ilmuilmu kebudayaan. Dengan demikian, kebudayaanlah yang menjembatani sains dan agama. Jadi dalam model ini, ilmu-ilmu kealaman dan ilmuilmu keagamaan dijembatani oleh humaniora dan ilmu-ilmu kebudayaan.

Sebagai koreksi terhadap model diadik dan triadik komplementer, telah dikembangkan sebuah model tetradik. Salah satu interpretasi dari model diadik komplementer adalah identifikasi komplementasi "sains/agama" dengan komplementasi "luar/dalam". Pemilihan "luar/dalam" identik dengan pemilahan “objek/subjek" dalam perspektif 
epistemologi. Pemilihan ini untuk sementara, menurut pemikir Amerika sepereti Ken Wilber, dianggap tidak mencukupi untuk memahami fenomena budaya.

Wilber tampaknya memerlukan komplementasi baru untuk melengkapi komplementasikomplementasi modernis yang disebut terdahulu. Komplementasi baru itu adalah komplementasi postmodernis "satu/banyak". Komplementasi itu disebut Ken Wilber sebagai komplementasi “individual/sosial". Dengan adanya dua komplementasi, yang lama dan yang baru, maka realitas budaya dibagi menjadi empat kuadran di mana satu lingkaran dibelah oleh dua buah sumbu komplementasi yang saling tegak lurus satu sama lainnya: horizontal dan vertikal. Pada diagram empat kuadran Wilber ini, sumbu individual/sosial diletakkan secara horizontal, dengan individualitas di sebelah kiri dan sosialitas di sebelah kanan, dan sumbu interior/eksterior diletakkan pada arah vertikal dengan interioritas sebelah kiri dan eksterioritas di sebelah kanan.

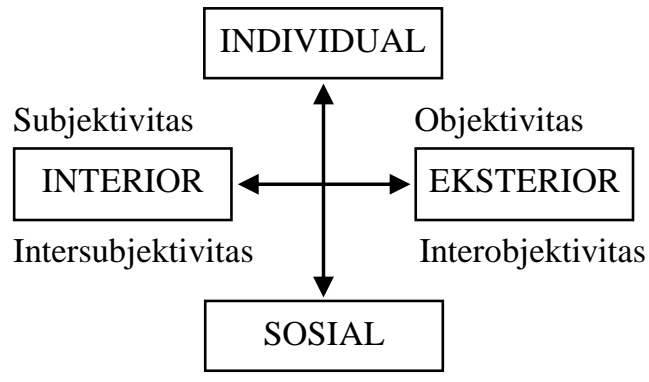

Dalam diagram Wilber, kuadran kiri atas berkaitan dengan subjektivitas, yang menjadi topik bagi psikologi Barat dan mistisisme Timur, dan kuadran kanan atas berkaitan dengan objektivitas yang menjadi topik bagi sains atau ilmuilmu kealaman. Sedangkan kuadran kiri bawah berkaitan dengan intersubjektivitas yang menjadi topik bahasan humaniora atau kebudayaan. Sementara itu, kuadran kanan bawah menyangkut interobjektivitas yang mempelajari gabungan objek-objek yang disebut Wilber sebagai masyarakat, tetapi tampaknya lebih sesuai jika diberi judul teknologi. Dengan demikian, ada empat kuadran keilmuan, yaitu ilmu-ilmu kealaman (kanan atas), ilmu-ilmu keagamaan (kiri atas), ilmu-ilmu kebudayaan (kiri bawah), dan ilmu-ilmu keteknikan (kanan bawah).

Satu kelemahan pokok dari model Wilber ini adalah bagaimana dia meletakkan semua jenis ilmu itu 
setara satu sama lainnya. Untuk dapat menanggulanginya, kita dapat membandingkan model tetradik Ken Wilber dengan model pentadik integralisme Islam sebagai berikut Kategori-kategori objektivitas, interobjektivitas, intersubjektivitas, dan subjektivitas Wilber masingmasingnya bersesuaian dengan kategori-kategori materi, energi, informasi, dan nilai-nilai dalam integralisme Islam. Akan tetapi, ada Integralisme Islam yang juga mengenal kategori kelima, yaitu kategori sumber yang merupakan sumber esensial bagi kategori nilainilai.

Berbeda dengan integralisme universal Wilber, kelima kategori integralisme Islam tersebut bukan tersusun secara sejajar, malainkan tersusun sebagai suatu perjenjangan menegak atau hierarki. Hierarki itu berjenjang dari materi ke sumber, melalui energi, informasi, dan nilainilai. Sebenarnya, hierarki kategori integralis ini tidak berbeda dengan perumusan kontemporer bagi hierarki dasar yang secara implisit terstruktur dalam berbagai tradisi pemikiran Islam: tasawuf, fiqih, kalam, dan hikmat.
Dalam tradisi tasawuf, kelima kategori itu bersesuaian dengan jism, nafs, 'aql, qalb, dan ruh. Dalam tradisi fiqih, kelima kategori itu bersesuaian dengan hierarki sumber hukum 'urf, ijma', ijtihad, Sunnah, dan Qur'an. Dalam tradisi teologis ilmu kalam, kelima kategori itu bersesuaian dengan khalqillah, sunnatullah, amrullah, shifatullah, dan dzatullah. Dalam tradisi filsafat atau hikmat Islam kelima, kategori itu bersesuaian dengan ilah maddiyyah, ilah fa'iliyyah, ilah shuriyyah, ilah gha'iyyah, dan ilah tammah.

Keempat intisari ilmu-ilmu Islam itu masing-masing dapat dijadikan sebagai paradigmaparadigma epistemologis, aksiologis, teologis, dan kosmologis bagi sains. Keempat paradigma sains islami itu dapat menggantikan tiga paradigma sains modern; rasionalisme sebagai paradigma epistemologis, humanisme sebagai paradigma aksiologis, dan materialisme sebagai paradigma ontologis.

Begitulah cara berfikir sains, pengetahuan faktual tentang alam adalah basis dan pengetahuan teoretik adalah struktur, sedangkan paradigma adalah superstruktur di atas atau di 
luar sains. Sudut pandang ini adalah sudut pandang materialisme yang menganggap materi sebagai satusatunya realitas. Sains adalah representasi dari alam yang objektif dalam pikiran manusia yang merupakan satu aspek saja dari otak manusia yang merupakan bagian dari alam.

Tentu saja pandangan itu berbeda dengan pandangan islam tentang sains atau ilmu pada umumnya. Dalam diri manusia terdapat ruh sebagai substansi yang bersifat imateriil. Sedangkan alam tak lain adalah manifestasi kreativitas Tuhan sebagai ciptaan yang tentu saja dibentuk berdasarkan Ilmu-Nya. Itulah sebabnya, berbeda dengan sains modern yang menganggap alam materiil sebagai basis realitas, maka sains islami melihat wahyu Tuhan sebagai basis realitas. Itulah sebabnya kita memiliki piramida ilmu dengan struktur kebalikan dari struktur sains modern.

Dari diagram di atas, kita dapat melihat bahwa orientasi sains Islam bukan saja berkebalikan dari sains modern yang dikembangkan di Barat, melainkan juga terdapat stratifikasi yang lebih banyak pada struktur ilmu.
Paradigma ilmu dinyatakan secara eksplisit dan dibangun di atas kebenaran wahyu berupa firmanfirman-Nya yang tertulis dalam kitab suci Al-Karim yang diwahyukan kepada nabi dan rasul-Nya yang terakhir: Muhammad SAW.

Dari diagram itu, kita juga melihat bahwa ilmu Islam tidak bersifat rasional empiris dan objektif belaka, tetapi juga bersifat intuitif religius. Hal ini disebabkan karena dalam Islam kita mengenal integralitas individu manusia dari tubuh atau jism ke ruh melalui nafs, 'aql, dan qalb yang bersesuaian dengan empirisitas, rasionalitas, dan intuitivitas ilmu Islam. Ketiga karakteristik itu adalah pelengkap dari objektivitas dan religiusitas sains.

Oleh sebab itu, Islam tidak hanya mengenal ilmu-ilmu kealaman dan ilmu-ilmu kemanusiaan, tetapi juga ilmu-ilmu keagamaan yang intisari filosofinya merupakan paradigma bagi kedua ilmu yang disebutkan terdahulu. Misalnya, paradigma epistemologis keilmuan Islam adalah hierarki organ pengetahuan dari jism hingga ruh, seperti yang diajarkan oleh tasawuf, dan paradigma aksiologis keilmuan 
Islam adalah hierarki nilai dari 'urfi hingga qur'ani. Sedangkan paradigma ontologis keilmuan Islam adalah hierarki dari kausa materiil yang merupakan ciptaan-Nya hingga kausa prima, yaitu Zat-Nya yang merupakan kenyataan akhir yang mutlak. Semuanya mencerminkan struktur pentadik keilmuan Islam.

Dari sudut lain, kita dapat melihat bahwa struktur pentadik ini dapat meletakkan klasifikasi keilmuan Islam menjadi empat, yaitu ilmu-ilmu keagamaan, ilmu-ilmu kebudayaan, ilmu-ilmu terapan, dan ilmu-ilmu kealaman bersesuaian dengan kategori-kategori integral nilai, informasi, energi, dan materi. Dalam pandangan keilmuan Islam, keempat ilmu tersebut mendapat ruhnya dari ilmu-ilmu Al-Quran, yang bersesuaian dengan kategori sumber, dan merupakan sumber ilham ilmiah yang tak henti-hentinya.

\section{KESIMPULAN}

Pada bagian akhir ini, kesimpulan sebagai jawaban atas perumusan masalah penelitian. Berdasarkan penggalian informasi yang berujung pada perolehan temuan di lapangan dan dibangunnya proposisi mayor, maka kesimpulan yang bisa diperoleh adalah sebagai berikut :

\section{Hal-hal yang mendasari} Pola Interaksi Sosial

Hal-hal yang mendasari terbentuknya pola interaksi sosial di SMA Selamat Pagi Indonesia adalah : Warga belajar (guru/siswa) baik secara mikro/makro diciptakan menjadi bangsa yang majemuk, Berpedoman pada konsep Kebudayaan, peribadatan, mengabdikan diri dalam kehidupan, Pada pelajaran agama selalu di ajarkan toleransi, saling mengasihi sesama dan mengabdi kepada Tuhan, Toleransi kepada pemeluk agama lain. SMA Selamat Pagi Indonesia Batu merupakakn pendidikan yang membentuk karakter putraputri siswanya cinta tanah air, Republik Indonesia, walaupun perbedaan keragaman budaya yang dibawa oleh masingmasing siswa dari daerah asalnya, agamanya, 
budayanya, bahasa daerahnya, itu semua tidak menjadi penghambat dalam proses pembentukan karakter putraputri Indonesia yang berjiwa menghormati

multikulturalisme serta bersifat prurallisme

merupakan karakter

Kebhinekaan Tunggal Ika yang dalam terjemahannya kepribadian bangsa Indonesia yang harmonis, demokratis, yang bertolerans.

\section{Proses}

terbentuknya

\section{Toleransi}

Proses terbentuknya budaya toleransi di SMA Selamat Pagi Indonesia Batu adalah karena adanya metode PAKSA (Pray, Attitude, Knowledge, Skill, Action). Atas dasar pemikiran ini, maka dibentuklah suatu lembaga pendidikan yang didalamnya diajarkan Eksistensi Keberagaman Budaya, Agama didukung dengan penanaman multikultural lintas etnis dan pendalaman keyakinan dalam memahami ajaran agama yang diyakini oleh para siswanya. - SMA Selamat Pagi Indonesia mempunyai fungsi sebagaimana yang digariskan dalam Konferensi Nasional Sekolah yang diperlakukan khusus, sebagai berikut : sebagai alat kesaksian dan alat untuk mendemonstrasikan cinta tanah air sebagai alat pelayanan yang dipanggil untuk berpartisipasi dalam meningkatkan pendidikan rakyat baik secara alternatif maupun secara kauntitatif, sebagai alat komunikasi antara warga negara dan masyarakat, yakni menumbuhkan pengertian tentang keberadaan, sifat dan maksud warga negara dalam kehidupannya di tengahtengah masyarakat yang majemuk (Multi kultur) yang mempunyai keragaman Budaya, Adat, Suku, Agama, dalam wadah Bhineka Tunggal Ika. 
3. Pemaknaan toleransi

$$
\text { Pemaknaan tradisi }
$$

toleransi atau peradapan pergaulan/perkumpulan di SMA Selamat Pagi Indonesia yang berlatar multikultural yaitu dengan adanya sifat integritas warga sekolah (terutama peserta didik) yang bisa dimaknai sebagai, "Indonesia Kecil", "Indonesia Mini", dan "Sekolah Pembauran".

\section{DAFTAR PUSTAKA}

Azra', Azymardi (peny). 1989. Perspektif Islam di Asia Tenggara. Jakarta: Yayasan Obor Indonesia.

Abdulsyani. 2002. Sosiologi, Skematika, Teori, dan Terapan. Jakarta: Bumi Aksara.

Baharuddin, Magni. 2005. Pendidikan Pada Era Desentralisasi Dalam Perspektif Sosiologis: Disertasi, Malang: Universitas Merdeka.

Bactiar W. 2006. Sosiologi Klasik, Dari Comte hingga Parsons. Bandung: Remaja Rosdakarya.

Ken Wilber. 1998 .The Marriage of Sense and Soul: Integrating Science and Religion,
Shambala Publications, Boston. Model Max Wilber ini dapat dipandang sebagai sebuah model integrasi sains dan agama.

Munir, Abdul Mulkhan. 2006. Pendidikan Multikultural. Yogyakarta: Pustaka Pelajar.

Mahfud Choirul. 2009. Pendidikan Multikultural. Cet. III. Yogyakarta: Pustaka Pelajar.

Ritzer, George - Goodman, J. Douglas. 2005. Teori Sosiologi Modern. Jakarta: Prenada Media.

Spredley. $1980 . \quad$ Participant Observation. Amerika: Holt Renehart and Winston. 